\title{
1. A feminist case for leadership
}

\section{Amanda Sinclair ${ }^{1}$}

On 10 October 2012, Australia's then Prime Minister, Julia Gillard, addressed the Australian Parliament in response to a motion put by Opposition Leader Tony Abbott. While the motion concerned the future of disgraced Speaker, Peter Slipper, Gillard's speech was a call to, and invocation of, feminist leadership. Gillard used the occasion to draw attention to a concerted campaign of misogynistic, sexist attacks from the Opposition and some of their associates, not just towards herself but also towards Australian women in general.

Julia Gillard's speech followed earlier concerns expressed by prominent feminists - for example, Moira Rayner and Anne Summers - about the escalating sexism in public commentary about the prime minister. ${ }^{2}$ For example, Summers argues that a new and contagious level of misogyny has been given voice via social media sites, evidencing a level of discrimination and bullying that would be treated as illegal were it to occur in a company.

Why can the prime minister's speech be seen as a call to and example of feminist leadership? I argue in this chapter that feminism brings with it an insistence on facing squarely several things. First, it demands we look at the sustained, yet routinised and systemic way in which women are demeaned, discriminated against and subordinated because of their sex. Second, feminism helps us understand why the special category of women with power (leaders) will attract particularly vicious and brutal efforts to drive women into silence or submission. Third, feminism brings us theories and ways of comprehending the 'underbelly' of leadership: the hubris that often takes sexually exploitative forms that we have seen played out in the demise of America's Central Intelligence Agency chief David Petraeus. Gillard's speech invited listeners to notice the pernicious and insidious ways sexism continues to work against women, and to see how public platforms of leadership are often used, consciously and unconsciously, to advance this agenda. Women's efforts towards leadership take place against the backdrop of women's subordination. For example, women's bodies are scrutinised and routinely measured against sex stereotypes, portraying them as less leaderlike. ${ }^{3}$ Though some may argue that instances of outright discrimination have

1 The University of Melbourne.

2 Moira Rayner, 'Gillard, Bligh and Leadership in a Crisis', Eureka Street, 7 January 2011; Anne Summers, 'The Political Persecution of Australia's First Female Prime Minister', Human Rights and Social Justice Lecture, University of Newcastle, 31 August 2012. See also Amanda Lohrey, 'A Matter of Context: Gillard and the Press Gallery', The Monthly 84 (November 2012); and Judith Brett, 'They Had it Coming: Gillard and the Misogynists', The Monthly 84 (November 2012).

3 Amanda Sinclair, 'Body Possibilities in Leadership', Leadership 1(4) (2005): 387-406; and Amanda Sinclair, 'Leading with Body', in Handbook of Gender, Work and Organization, eds E. Jeanes, D. Knights and P. Martin 
been reduced, there is plenty of evidence of emerging forms of media in which women are routinely derogated and treated as sex objects. This backdrop shapes how women are seen, and their experiences in public life, in turn affecting their appetite for leadership.

While leadership has become a popular ideal, there have been few explorations of both the problems with and the possibilities of leadership from a feminist point of view. ${ }^{4}$ If gender is recognised as an issue, it is through noting women's 'lack of fit' for leadership, or the need to make 'the business case' for appointing women more persuasive. It is understandable that women and especially feminist leaders and scholars have been wary of leadership. Leadership as the lionisation of the achievement of individuals in powerful, privileged positions is the antithesis of what many women have fought for. Indigenous leader Lillian Holt echoes the views of many when she suggests 'leadership is a white male idea'.

Yet the argument of this chapter (and indeed to some extent this collection) is that while we might oppose traditional constructs of leadership, women have a strong interest in the broader phenomena of leadership. How have women influenced and changed the public agenda and improved the life experiences of the people around and following after them? Precisely because leadership has become such a powerful discourse, with people at all levels of society being urged to undertake more leadership, it is vital to deconstruct, interrogate and reapproach leadership from a feminist point of view.

In the first part of this chapter, I define and provide a short history of leadership, including the rise of interest in women and leadership. In the second part of this chapter, I explore leadership from a feminist perspective. Scholars and those with a feminist perspective have been conceptualising and critiquing organisation, management and leadership throughout the period of leadership's ascendancy. Women activists and leaders have, and are, reorienting our understandings,

(New York: John Wiley \& Sons, 2011), 117-30.

4 Exceptions include studies of feminist organisation that discuss leadership tangentially. See, for example: Myra Marx Ferree and Patricia Yancey Martin, Feminist Organizations: Harvest of the New Women's Movement (Philadelphia: Temple University Press, 1995); Marta Calas and Linda Smircich, 'From "the Woman's" Point of View: Feminist Approaches to Organization Studies', in Handbook of Organization Studies, eds Stuart Clegg, C. Hardy and W. Nord (Thousand Oaks, Calif.: Sage, 1996), 218-57; and Karen Lee Ashcraft, 'Organized Dissonance: Feminist Bureaucracy as Hybrid Form', Academy of Management Journal 44(6) (2001): 1301-22. On feminist perspectives on leadership, see, for example: Susan Carroll, 'Feminist Scholarship on Political Leadership', in Leadership: Multidisciplinary Perspectives, ed. Barbara Kellerman (Englewood Cliffs, NJ: Prentice Hall, 1984); Jill Blackmore, 'Disrupting Notions of Leadership from Feminist Postcolonial Positions', International Journal of Leadership in Education: Theory and Practice 13(1) (2010): 1-6.

5 Quoted in Amanda Sinclair, Leadership for the Disillusioned: Moving beyond Myths and Heroes to Leading that Liberates (Sydney: Allen \& Unwin, 2007). 
public images and imagination about what good leadership is. Drawing on this work, I make a 'feminist case' for how leadership should be recognised and researched. ${ }^{6}$

\section{Leadership: Definitions and a brief history}

Leadership is not a position or a person but a process of influence, often aimed at mobilising people towards change - for example, in values, attitudes, approaches, behaviours and ideologies. ${ }^{7}$ Recent research on 'adaptive leadership' explores how to exercise leadership with less authority (the formal power that comes from position). Scholars with an interest in adaptive leadership focus on complex public policy and community problems, where the leadership task might involve, for example, supporting groups to face realities and accept responsibilities, creating opportunities and encouraging aspiring leaders to foster social learning or sustainable problem-solving. ${ }^{8}$ In this version, leaders are less likely to be out front, telling followers what to do, and more likely to be in groups, working from within, between, sometimes on the edge or from below.

Leadership therefore can be exercised by individuals located in the middle or at the bottom of organisations, by people without formal authority as much as by CEOs and prime ministers. These views of leadership are consistent with feminist formulations. For example, in her feminist analysis of political leadership, Susan Carroll defines an effective leader as 'one who empowers others to act in their own interests, rather than one who induces others to behave in a manner consistent with the goals and desires of the leader' ${ }^{9}$ Leadership is only comprehensible in relation to its educational, empowering and nurturing effects for followers.

Yet these understandings of leadership are recent views. Scholar Joe Raelin observes there is a 'long history in institutional thought and practice of considering leadership as an individual property'.$^{10}$ Further, when you ask

\footnotetext{
6 The title of this chapter draws on Kathy Ferguson's critique of bureaucracy titled The Feminist Case against Bureaucracy (Philadelphia: Temple University Press, 1984). In contrast with Ferguson, who argued that the logic of bureaucracy was fundamentally antithetical to feminism, I suggest there is value in applying a feminist lens and intent to leadership. See also Hester Eisenstein, 'The Australian Femocratic Experiment: A Feminist Case for Bureaucracy', in Feminist Organizations: Harvest of the New Women's Movement, eds Myra Marx Ferree and Patricia Yancey Martin (Philadelphia: Temple University Press, 1995), 69-83.

7 Mary Uhl Bien, 'Relational Leadership Theory: Exploring the Social Processes of Leadership and Organizing', The Leadership Quarterly 17 (2006): 668.

8 For treatments of adaptive leadership, see: Ron Heifetz, Leadership without Easy Answers (Cambridge, Mass.: Belknap Press, 1994); Ron Heifetz and Marty Linsky, Leadership on the Line: Staying Alive through the Dangers of Leading (Boston: Harvard Business School Press, 2002); and Dean Williams, Real Leadership: Helping People and Organizations Face their Toughest Challenges (San Francisco: Berrett-Koehler, 2005).

9 Carroll, 'Feminist Scholarship', 142.

10 Joseph Raelin, ‘From Leadership-as-Practice to Leaderful Practice', Leadership 7(2) (2011): 195.
} 
people about leadership they often nominate performances of toughness or 'greatness'. And 'greatness' is an adjective that is almost always applied to men. Constructions of modern leadership remain, according to Keith Grint, 'irredeemably masculine, heroic, individualist and normative in orientation and nature'. ${ }^{11}$ An alarming amount of common wisdom about leadership derives directly from the military. In research that colleagues and I undertook in the 1990s, one of the key themes that emerged from interviewing CEOs was the idea of leadership as combat, involving 'rallying the troops' and 'taking no prisoners' ${ }^{12}$ Further and particularly in the United States, which has dominated leadership research, the psychological and social sciences have been concentrating on questions about selecting and training leaders. ${ }^{13}$ Aspects of an idealised American national character-individualism, self-reliance, competitiveness, assertiveness - have thus come to underpin much leadership theorising, development and training. ${ }^{14}$

The continuing appeal of notions of tough, heroic leadership is important to those of us with an interest in women's leadership because we can also notice how theories of leadership have been remarkably adaptive. As soon as a powerful critique begins to be mobilised about leadership, we see emerging a new emphasis on 'collaborative', 'empowered' or 'relational' leadership, often with sporting coaches given as exemplars. We are tempted to sigh with relief at this point and say, 'Oh, things must be changing'. But many of these manoeuvres provide a veneer of doing leadership differently, of looking more enlightened but without any systematic analysis of power, who has it and how it is reproduced in ways that render women less likely as leaders. In another example, since the late 1980s there has been a nostalgic turn to notions of transformational and charismatic leadership. While studies have shown women exhibit at least as many transformational behaviours as men, when they do so they are rarely judged as favourably as men. ${ }^{15}$

\section{Interest in women's leadership}

From the late 1970s and 1980s and alongside the rise of second-wave feminism and a focus on affirmative action in many Western countries, feminist scholarship

\footnotetext{
11 Keith Grint, 'A History of Leadership', in The Sage Handbook of Leadership, eds Alan Bryman, David Collinson, Keith Grint, Brad Jackson and Mary Uhl-Bien (Sage: London, 2011), 8.

12 Amanda Sinclair, Trials at the Top: Chief Executives Talk about Men, Women and the Australian Executive Culture (Melbourne: The Australian Centre, 1994).

13 Loren Baritz, The Servants of Power: A History of the Use of Social Science (Connecticut: Wesleyan University Press, 1960).

14 Barbara Kellerman, ed., Bad Leadership: What it is, How it Happens, Why it Matters (Boston, Mass.: Harvard Business School Press, 2004), 10.

15 For one exception, see Beverly Alimo-Metcalfe's work on transformational leadership.
} 
began to document women's experiences of organising and influencing the public agenda, including in Australia. ${ }^{16}$ It was also during this period that leadership as an idea was particularly taken up by business schools, management theorists and social psychologists.

It is, however, notable the two areas of thinking were rarely put together. Scholars - then and still - focus on business and politics as natural homes for leadership while neglecting women's leadership in communities and schools. ${ }^{17}$ As Jeff Hearn and Wendy Parkin note, much of the early literature on 'women in management' was 'business oriented, American in origin and in cultural assumptions, often unduly optimistic about the immediate possibilities for change' ${ }^{18}$ A psychological preoccupation became common, with studies focusing on the qualities women needed in management, and whether there were enduring sex differences that meant women and men led and managed differently. The 'sex differences' approach to women in management generated considerable research from the late 1970s. Researchers concluded that there was little difference due to sex in achievement motivation, risk-taking, task persistence and other significant managerial skills. Hence, even early research demonstrated that women are not psychologically handicapped for leadership but rather face a barrage of gendered assumptions and stereotypes about their fitness for leadership, which are translated into discriminatory norms and organisational practices in areas such as recruitment and promotion.

By the late 1980s and early 1990s, a new interest specifically focused on women and leadership was emerging. Again, much of the early work came from American business-oriented researchers. Judy Rosener, writing in Harvard Business Review in 1990, argued that there was now a 'second wave' of women leaders who no longer had to mimic the 'command and control' male model of organisational leadership. ${ }^{19}$ Further, they are 'succeeding because of - not in spite of - certain characteristics generally considered to be "feminine" and inappropriate in leaders' ${ }^{20}$ Rosener makes the case that these women are 'transformational' or distinctly 'interactive' in their leadership. 'More

16 In Australia, the federal Sex Discrimination Act was passed in 1984 and the Affirmative Action Act in 1986. This was a period characterised by increased opportunities for women, especially in politics and the federal bureaucracy. See Marian Sawer's research - for example: Sisters in Suits: Women and Public Policy in Australia (Sydney: Allen \& Unwin, 1990); and also Hester Eisenstein's work-for example: Inside Agitators: Australian Femocrats and the State (Sydney: Allen \& Unwin, 1996).

17 For an alternative view of the role of women in community leadership, see Marian Sawer and Merrindahl Andrew's Chapter 15, in this volume.

18 Jeff Hearn and Wendy Parkin, 'Women, Men and Leadership: A Critical Review of Assumptions, Practices and Change in the Industrialized Nations', in Women in Management Worldwide, eds N. Adler and D. Izraeli (Armonk, NY: M. E. Sharpe, 1988), 24. On the dangers of being overoptimistic about women's progress, see also Linda Blum and Vicki Smith, 'Women's Mobility in the Corporation: A Critique of the Politics of Optimism', Signs: Journal of Women in Culture and Society 13(3) (1988): 528-45.

19 Judy Rosener, 'Ways Women Lead', Harvard Business Review November-December 1990: 119-25.

20 Ibid., 120 
specifically, the women encourage participation, share power and information, enhance other people's self-worth, and get others excited about their work.'21 This form of leadership is highly effective, she argues, and organisations should be open to expanding their definitions of effective leadership.

Rosener's argument - that women lead differently to men-elicited controversy, with researchers noting the consequences of identifying a 'feminine' or 'women's' style of leading. For example, writing that deplores the effects of stereotyping is used to create new stereotypes - for example, that women are more empathetic and people-friendly, and therefore suited to 'support' roles rather than leadership ones. Such new stereotypes are not benign. They are deployed to set higher standards for women in some areas and marginalise them in others.

Long-time scholar of women's leadership Alice Eagly observes the contradictions in much of the popular research. ${ }^{22}$ Women leaders are identified as having a 'female advantage': showing up as consistently demonstrating qualities of transformational leadership such as 'individualised consideration', 'inspirational motivation' and 'intellectual stimulation'. They are, however, simultaneously disadvantaged by stereotypes of leadership that resemble stereotypes of menthat is, agentic, confident, aggressive and self-determined. Eagly concludes: 'men can seem usual or natural in most leadership roles ... people more easily credit men with leadership ability and more readily accept them as leaders.' ${ }^{23}$ She notes that though prejudices against women leaders dropped significantly from the 1970s and 1980s, there was evidence of plateauing or even reversal of this trend in recent years, especially in traditionally masculine fields.

\section{Bringing a feminist perspective to leadership}

Why make a 'feminist case' for leadership? In this second part of the chapter, I show how feminist work deepens, challenges and in some cases subverts understandings of leadership. Feminism as a perspective and field has undergone enormous changes through the second part of the twentieth century and into the twenty-first. ${ }^{24}$ Initially, distinctions between radical and liberal feminism and, later, the impact of social theories such as post-structuralism, postmodernism and postcolonial scholarship have produced rich divergences in feminist thinking,

\footnotetext{
21 Ibid.

22 Alice Eagly, 'Female Leadership Advantage and Disadvantage: Resolving the Contradiction', Leadership. Volume IV: 2005-2009, eds David Collinson, Keith Grint and Brad Jackson (London: Sage, 2011), 251-72.

23 Ibid., 257.

24 See, for example: Chris Weedon, Feminist Practice and Poststructural Theory (Oxford: Blackwell, 1987); and Sandra Harding's discussion of whether there is a feminist methodology in 'Introduction: Is there a Feminist Method?', in Feminism and Methodology, ed. Sandra Harding (Bloomington: Indiana University Press, 1987), 1-14.
} 
especially on theorisations of power and hierarchy, the agency of women and the risks of women speaking for other women. For example, feminists differ on whether women organising can, or must, dispense with hierarchy and formal leaders. Writing by women of colour, Indigenous and postcolonial scholars has critiqued the earlier assumptions by some feminists that all women share the same interests. ${ }^{25}$ For many, a response is to recognise there are many feminisms, not one. ${ }^{26}$

Building on this notion of multiple and unfolding feminisms, I seek here to identify and explore some themes and emphases in feminist work that are of central importance to leadership. ${ }^{27}$ These include the following.

1. A starting point that knowledge has often been built on male experience and is designed to serve men's interests; feminism seeks to reinscribe and reinstate the experience of women in the historical and intellectual records. Hence, feminists are aiming for change in patriarchal structures.

2. A determination to focus on power and privilege, especially manifestations of structural power in gender relations, which often escape attention.

3. A commitment to, and interest in, non-hierarchical relations in the ways groups and organisations are formed and run and in the way research is done.

4. An interest in those areas of public and private experience that traditional patriarchal accounts tend to obscure, such as theorising about bodies.

5. Enactment of reflexivity in research methods and seeking to empower others through research; ${ }^{28}$ owning one's own context and recognising how that affects what we see and say; and a preference towards 'textual multiplicity' in writing. ${ }^{29}$

Women have been conceptualising and critiquing bureaucracy and organisation, management and leadership for many decades, starting with the pioneering work of Mary Parker Follet in the first half of the twentieth century. Researchers have

25 For example, Bell Hooks, Feminist Theory from Margin to Centre (Boston: South End, 1984), and Talking Back: Thinking Feminist, Thinking Black (Boston: South End, 1989); Chandra Talpede Mohanty, Feminism without Borders: Decolonizing Theory, Practicing Solidarity (Durham, NC, and London: Duke University Press 2003), 47.

26 Jean Lau Chin, 'Transforming Leadership with Diverse Feminist Voices', in Women and Leadership: Transforming Visions and Diverse Voices, eds Jean Lau Chin, Bernice Lott, Joy Rice and Janice Sanchez-Hucles (Malden, Mass.: Blackwell, 2007).

27 See also Judith Pringle, 'Feminism and Management: Critique and Contribution', in New Directions in Management, eds Alex Kouzmin, Leonie Still and P. Clarke (Sydney: McGraw Hill, 1994); and Patricia Yancey Martin, 'Feminist Practice in Organizations: Implications for Management', in Women in Management, ed. Ellen Fagenson (Thousand Oaks, Calif.: Sage, 1994).

28 Harding, 'Introduction'; and Michelle Young and Linda Skrla, eds, Reconsidering Feminist Research in Educational Leadership (Albany, NY: State University of New York Press, 2003).

29 Patti Lather, Getting Smart: Feminist Research and Pedagogy with/in the Postmodern (New York: Routledge, 1991). 
argued that Follet challenged conventional leadership approaches and made a case for 'transformational leadership' long before James Macgregor Burns, the political scientist credited with originating the term in $1978 .{ }^{30}$

During the late 1970s and 1980s, as the field of contemporary leadership studies started to gain momentum, gender scholars and feminists also began to deconstruct organisational and leadership life. Instead of focusing on women as the 'other' in management who somehow needed to 'learn the ropes', researchers documented how organisations and leadership were set up to maintain a gender order in which masculinities were privileged. ${ }^{31}$ Administrative logic and 'meritbased' principles and practices are not neutral but designed, in the words of Australian scholar Clare Burton, to 'mobilise masculine bias'. ${ }^{32}$ Burton and others have thus argued that our focus should shift from individual women and their experiences in organisations to the structures in which they are located, including the construction and maintenance of masculinities.

Throughout the 1990s there emerged a new focus on masculinities and management. Sociologists such as R. W. Connell, as well as critical and feminist organisational theorists, began to map the cultural norms of hegemonic masculinity in how to be a manager and leader. ${ }^{33}$ Until this time leadership had mostly been treated as a 'gender-free' zone (unless of course you were a woman, when usually one's gender was rendered problematic). In the weighty handbooks of leadership research, there were few if any entries on gender, masculinity or sexuality. In my own research in the early 1990s, I remember clearly the moment when I realised that in order to understand the obstacles to women aspiring to leadership, I needed to shift my focus from women to men. ${ }^{34} \mathrm{I}$ argued the need to dissect the construction of male executive cultures, including the way in which leadership was often reinforced by male heterosexuality. In contrast, women's sexuality or sense of sexual identity was seen to undermine their leadership, needing to be repressed or camouflaged. Not surprisingly, my focus on masculinities was unpopular, especially among male audiences. It has always been far more comfortable to keep the 'problem' of gender located in women and to hold women responsible for fixing their own exclusion.

\footnotetext{
30 Pauline Graham, Mary Parker Follett-Prophet of Management: A Celebration of Writings from the $1920 \mathrm{~s}$ (Boston: Harvard Business School Press, 1995).

31 Joan Acker, 'Hierarchies, Jobs, Bodies', Gender and Society 4 (2) (1990): 139-58.

32 Clare Burton, 'Merit and Gender: Organizations and the Mobilization of Masculine Bias', Australian Journal of Social Issues 22(2) (1987): 424-435.

33 R. W. Connell, Gender and Power: Society, the Person and Sexual Politics (Cambridge: Polity Press, 1987), and Masculinities (Sydney: Allen \& Unwin, 1995); Cynthia Cockburn, In the Way of Women: Men's Resistance to Sex Equality in Organizations (London: Macmillan, 1991); David Collinson and Jeff Hearn, Men as Managers, Managers as Men: Critical Perspectives on Men, Masculinities and Managements (London: Sage, 1996); and Joan Eveline, 'The Worry of Going Limp: Are You Keeping Up in Senior Management?', Australian Feminist Studies 11(3) (1996): 65-79.

34 Sinclair, Trials at the Top.
} 
Shifting the focus from the 'problem' of women to understanding the means by which male cultures are perpetuated in leadership has therefore been a key contribution. ${ }^{35}$ In their analysis of leadership writing, feminist organisational scholars Marta Calas and Linda Smircich argue that leadership is about seduction. The words 'seduction' and 'leadership' have common origins with the Latin root of seduction, se ducere, meaning 'lead' or 'to lead astray'. Calas and Smircich select and deconstruct sections of texts from four leadership 'gurus' whose work spans more than 50 years. They argue that leadership writing is complicit in reinforcing 'the homosocial libidinal economy of competitiveness and glory' as if it were the truth, and indeed, with each new discourse, a kind of deeper and more powerful truth. ${ }^{36}$

Many women and critical scholars have helped us see that leadership is not 'great deeds by great men' but a relational, discursive and intersubjective phenomena between people. ${ }^{37}$ Leadership is not simply the way someone does a job or activity, but rather a series of ways of talking and understanding that is prefigured by relations of power and knowledge. Accordingly, from this perspective, leadership is already a discursively produced, privileged ideology that casts some performances as leadership and others, such as what women do, as something less than leadership. Drawing on a discourse perspective changes our understanding of leadership as a predetermined power/language position made available only to designated individuals.

Related to this, women scholars have always been centrally interested in the relationship between leadership and power. Power has been neglected in most leadership texts, which often take the view that formal power is an unproblematic accompaniment of leadership. Because of their general lack of power, women have often been more attuned to its use and effects, as well as open to theorising alternatives. How is leadership used to centralise and entrench power in an elite, or how is leadership sometimes used to unmask power and reduce oppression? Further, how is power played out in more micro, intimate relationships and how do we exercise leadership in ways that minimise dominance and oppression ${ }^{38}$

One of the few areas of leadership research where women figure prominently in populations of leaders is in educational leadership in schools and universities.

35 Joan Eveline, 'The Politics of Advantage', Australian Feminist Studies 9(19) (1994): 129-54.

36 Marta Calas and Linda Smircich, 'Voicing Seduction to Silence Leadership', Organization Studies 12(4) (1991): 583.

37 See, for example: Jackie Ford, 'Discourses of Leadership: Gender, Identity and Contradiction in a UK Public Sector Organization', Leadership 2(1) (2006): 77-99, and 'Studying Leadership Critically: A Psychosocial Lens on Leadership Identities', Leadership 6(1) (2010): 47-65. Also Donna Ladkin, Rethinking Leadership: A New Look at Old Leadership Questions (Cheltenham, UK: Edward Elgar, 2010); Gail Fairhurst, Discursive Leadership: In Conversation with Leadership Psychology (Thousand Oaks, Calif.: Sage, 2007).

38 See, for example, Cynthia Cockburn's research of women leading the peace movement through dialogue with other women from opposing national, racial and cultural groups: The Space between Us (London: Zed Books, 1998), and From Where We Stand: War Women's Activism and Feminist Analysis (London: Zed Books, 2007). 
Here women principals and senior administrators have often been at the forefront of upholding more traditional educational values against intense market and corporatisation pressures. ${ }^{39}$ Both the women educational leaders and their researchers display a capacity to continually reflect and adjust around the balance of these tensions. Blackmore and Sachs describe their experience as one of living in contradictions - for example, between performing to new stakeholders and focusing on substantive educational and ethical issues: 'doing well' versus 'doing good'. ${ }^{40}$

Where women have some freedom to organise themselves differently, do feminist leadership patterns emerge? There has been extensive discussion about principles of feminist organising, particularly in international development and transnational networks, among postcolonial scholars, and feminist, Indigenous and other women's groups. ${ }^{41}$ This research documents that women organising consistently reject hierarchy, put effort into building relationships and empowering others, and emphasise collective achievement and responsibility, rather than the leadership of individuals. At the same time, collections exploring women's leadership usually find there is considerable diversity in the way women go about the job of leading despite a common interest in transforming outcomes to better serve women's interests. ${ }^{42}$ Partially this arises because of the contexts and constraints they must work around, within and against to do their leadership work.

Feminists and postcolonial scholars have critiqued models of leadership perpetuated by the dominance of elites and institutions such as the World Bank. A common thread is the focus on the discourses of colonialism, development and postcolonialism. Mohanty, for example, argues that genuine decolonisation that allows for the recovery of authentic indigenous values and culture is hindered by the embedded 'archive' of Western 'knowledge and systems, rules and values'.$^{43}$ She says that 'privilege nurtures blindness'. Feminist standpoint theory has advanced the idea that the perspectives of the marginalised and disempowered are a source of leadership. As Sandra Harding has also suggested,

39 Valerie Hall, Dancing on the Ceiling: A Study of Women Managers in Education (London: Paul Chapman, 1999); Jill Blackmore, Troubling Women: Feminism, Leadership and Educational Change (Buckingham, UK: Open University Press, 1999); Jill Blackmore and Judyth Sachs, Performing and Reforming Leaders: Gender, Educational Restructuring, and Organizational Change (Albany, NY: State University of New York Press, 2007); Young and Skrla, Reconsidering Feminist Research in Educational Leadership.

40 Blackmore and Sachs, Performing and Reforming Leaders.

41 For example, Ferree and Martin, Feminist Organizations; Kathleen Iannello, Decisions without Hierarchy: Feminist Interventions in Organization Theory and Practice (New York: Routledge, 1992); Helen Brown, Women Organizing (London: Taylor \& Francis, 1992); Chin et al., Women and Leadership; Cockburn, From Where We Stand.

42 Chin et al., Women and Leadership; Blackmore, Troubling Women; Ferree and Martin, Feminist Organizations.

43 Mohanty, Feminism without Borders, 47. 
standpoint research seeks to 'study up', revealing the norms and practices of dominant institutions whose impact may only be visible to those subordinated by them. ${ }^{44}$

Women scholars and leaders have also shown that leadership is often done in resistance and refusal from the bottom or the margins of society, rather than from formal positions at the top. Australian Indigenous scholars have increasingly documented the ways Indigenous women have enacted leadership in the face of the deliberate dehumanising sexism and racism that accompanied colonisation and which continue. ${ }^{45}$ In her work on Indigenous women's leadership, Pat Dudgeon argues that the women she has researched, including her grandmother (Martha) and great-grandmother (Lillian), demonstrated great leadership in their resistance, in their humour and in their pride and confidence as women. Though the historical records show Aboriginal women were treated as chattels, incubators and prostitutes, these women continued to lead: to stand up and push back, to fight for their families and assert their value as women. ${ }^{46}$

The past decade or so has also seen critical and women scholars drawing attention to the physical, embodied and aesthetic dimensions of leadership. ${ }^{47}$ The ideal organisation had always been portrayed as a rational, hierarchical one from which the 'disruptive' forces of sex and bodies had been eradicated. Women theorists and researchers have frequently been the ones who have dug beneath these myths to show how leadership by men often involves the performance of sexual identities, how being a successful leader is also about demonstrating hyper masculinity. ${ }^{48}$

This work also provides another set of explanations for the failure of leadership to be genuinely open to women. From the work of feminists and commentators like Anne Summers, we see that women, historically and now, are defined and subordinated by their female embodiment. ${ }^{49}$ The persistence of discrimination hints at deeper causes than the rational, logical ones. Enduring and powerful

\footnotetext{
44 Harding, Feminism and Methodology.

45 See, for example: Nerida White, 'Indigenous Australian Women's Leadership: Stayin' Strong against the Postcolonial Tide', International Journal of Leadership in Education 13(1) (2010): 7-25.

46 Pat Dudgeon, 'Mothers of Sin: Indigenous Women's Perceptions of their Identity and Sexuality/Gender', Paper delivered at University of Melbourne, 2011.

47 See, for example: Arja Ropo and Erica Sauer, 'Corporeal Leaders', in The Sage Handbook of New Approaches in Management and Organization, eds D. Barry and H. Hansen (London: Sage, 2008), 469-78; Donna Ladkin, 'The Enchantment of the Charismatic Leader: Charisma Reconsidered as Aesthetic Encounter', Leadership 2(2) (2006): 165-79; also Sinclair, 'Body Possibilities in Leadership'.

48 For a review of some of this work, see Sinclair, 'Leading with Body'.

49 Anne Summers, Damned Whores and God's Police: The Colonisation of Women in Australia (Melbourne: Penguin, 1974). See also Clare Burton, Subordination: Feminism and Social Theory (Sydney: George Allen \& Unwin, 1985).
} 
archetypes of maternal figures are activated when women have power. These archetypes include the omnipotent, controlling mother, and the seductress intent on distracting men from noble purpose. ${ }^{50}$

While the contribution of the research discussed here is much wider than leadership, it shows how the concepts and assumptions underpinning leadership are skewed towards male experience and are blind towards certain dimensions of leadership such as power and bodies. The importance and value of scholarly processes in leadership of deconstruction, critique and remaking cannot be understated. They provide the foundation for problematising assumptions about leadership and the distortions popular leadership discourses produce - in the media, in scholarship and in education.

\section{Conclusion}

Attention to women's leadership is welcome on many levels. It brings into the historical and contemporary public records women's leadership contributions. It celebrates the diversity and richness of the ways that women, often blocked by sexism and patriarchal norms, have found to resist and change the public agenda and to mobilise and empower others. The potent mixes of ingenuity, daring and determination described in chapters of this book are surely forms of leadership worth documenting and learning from.

Our role as feminists, scholars and activists, I have suggested, is, however, not just to celebrate this new level of attention. Rather, a feminist case for leadership requires us to bring values and perspectives from feminist research to the case for leadership, we must do the following.

1. Draw attention to the power and privilege reproduced in leadership and leadership research. Feminist researchers need to continue to resist the tide of thinking that focuses on women and what they need to do to 'get up to speed' to improve their eligibility for leadership. They need to continue fearlessly to redirect attention to the ways dominant forms of leadership reinforce the power of a narrow white male elite and continue the oppression of the majority of women, Indigenous peoples and those from non-white backgrounds.

50 See, for example: Barbara Poggio, 'Who's Afraid of Mothers?', and A. Telford, 'Maiden, Mother, Mistress, Monster: Controlled and Uncontrolled Female Power and the Curse of the Body in the Early Victorian NovelImplications of Historical Stereotyping for Women Managers', both in Interpreting the Maternal Organization, eds Heather Höpfl and Monica Kostera (London: Routledge, 2003); also Amanda Sinclair, Doing Leadership Differently (Melbourne: Melbourne University Press, 1998). 
2. Notice that leadership is itself a powerful discourse, which gives attention and legitimacy to our work, but which may also skew our analyses, causing us to lose sight of important values and experiences.

3. Not collude with the biases in leadership research towards individualism and universalism. Leaders rarely act alone. Yet myth-making often lionises the 'self-made man', while neglecting the contributions of those around the leader who do the unpaid, and some argue more important, work of nurturing and caring for families. There is also a particular bias in leadership research that seeks models and rules about how to lead. Such approaches already reflect a masculinist, ethnocentric bias. Rather, leadership work is often about proceeding in ambiguity, in circumstances of 'not knowing', and being open to diverse and shifting measures of success.

4. Be reflective about who we speak for and consider the effects of our work and scholarship on others. It is important that our work on women's leadership is useful, inspiring and empowering for women with less access to power.

Alongside celebrating women's contribution as leaders, I have argued there is an equally if not more important place for the kind of challenge made by former Prime Minister Gillard referred to in my introduction. The feminist task is to draw attention to the ways social and organisational structures, and the invocation of leadership's logic and discourse within those structures, continue to devalue women and their experiences. By locating women's leadership within the wider canvas of women's experiences, we see more clearly how leadership can both support and constrain human possibility.

\section{References}

Acker, Joan. 'Hierarchies, Jobs, Bodies.' Gender and Society 4(2) (1990): 139-58.

Alimo-Metcalfe, Beverly. 'An Investigation of Female and Male Constructs of Leadership and Empowerment.' Women in Management Review 10(2) (1995): 3-8.

Ashcraft, Karen Lee. 'Organized Dissonance: Feminist Bureaucracy as Hybrid Form.' Academy of Management Journal 44(6) (2001): 1301-22.

Baritz, Loren. The Servants of Power: A History of the Use of Social Science. Connecticut: Wesleyan University Press, 1960.

Boin, Arjen, Paul 't Hart, Eric Stern and Bengt Sundelius. The Politics of Crisis Management: Public Leadership under Pressure. Cambridge: Cambridge University Press, 2005. 
Diversity in Leadership: Australian women, past and present

Blackmore, Jill. Troubling Women: Feminism, Leadership and Educational Change. Buckingham, UK: Open University Press, 1999.

Blackmore, Jill. 'Disrupting Notions of Leadership from Feminist Postcolonial Positions.' International Journal of Leadership in Education: Theory and Practice 13(1) (2010): 1-6.

Blackmore, Jill and Judyth Sachs. Performing and Reforming Leaders: Gender, Educational Restructuring, and Organizational Change. Albany, NY: State University of New York Press, 2007.

Blum, Linda and Vicki Smith. 'Women's Mobility in the Corporation: A Critique of the Politics of Optimism.' Signs: Journal of Women in Culture and Society 13(3) (1988): 528-45.

Brett, Judith. 'They Had it Coming: Gillard and the Misogynists.' The Monthly 84 (November 2012). https://www.themonthly.com.au/issue/2012/ november/1351733161/judith-brett/they-had-it-coming.

Brown, Helen. Women Organizing. London: Taylor \& Francis, 1992.

Burton, Clare. Subordination: Feminism and Social Theory. Sydney: George Allen \& Unwin, 1985.

Burton, Clare. 'Merit and Gender: Organizations and the Mobilization of Masculine Bias.' Australian Journal of Social Issues 22(2) (1987): 424-35.

Burton, Clare. The Promise and the Price: The Struggle for Equal Opportunity in Women's Employment. Sydney: Allen \& Unwin, 1991.

Calas, Marta and Linda Smircich. 'Voicing Seduction to Silence Leadership.' Organization Studies 12(4) (1991): 567-602.

Calas, Marta and Linda Smircich. 'From "the Woman's" Point of View: Feminist Approaches to Organization Studies.' In Handbook of Organization Studies, edited by Stewart Clegg, Cynthia Hardy and William Nord, 218-57. Thousand Oaks, Calif.: Sage, 1996.

Carroll, Susan. 'Feminist Scholarship on Political Leadership.' In Leadership: Multidisciplinary Perspectives, edited by Barbara Kellerman, 139-56. Englewood Cliffs, NJ: Prentice Hall, 1984.

Chin, Jean Lau. 'Transforming Leadership with Diverse Feminist Voices.' In Women and Leadership: Transforming Visions and Diverse Voices, edited by Jean Lau Chin, Bernice Lott, Joy Rice and Janice Sanchez-Hucles, 355-62. Malden, Mass.: Blackwell, 2007. 
Cockburn, Cynthia. In the Way of Women: Men's Resistance to Sex Equality in Organizations. London: Macmillan, 1991.

Cockburn, Cynthia. The Space between Us. London: Zed Books, 1998. Cockburn, Cynthia. From Where We Stand: War Women's Activism and Feminist Analysis. London: Zed Books, 2007.

Collinson, David and Jeff Hearn. Men as Managers, Managers as Men: Critical Perspectives on Men, Masculinities and Managements. London: Sage, 1996.

Connell, R. W. Gender and Power: Society, the Person and Sexual Politics. Cambridge: Polity Press, 1987.

Connell, R. W. Masculinities. Sydney: Allen \& Unwin, 1995.

Cregan, Christina, Timothy Bartram and Pauline Stanton. 'Union Organizing as a Mobilizing Strategy: The Impact of Social Identity and Transformational Leadership on the Collectivism of Union Members.' British Journal of Industrial Relations 47(4) (2009): 701-22.

Dudgeon, Pat. 'Mothers of Sin: Indigenous Women's Perceptions of their Identity and Sexuality/Gender.' Paper delivered at University of Melbourne, 2011.

Eagly, Alice. 'Female Leadership Advantage and Disadvantage: Resolving the Contradiction.' In Leadership. Volume IV: 2005-2009, edited by David Collinson, Keith Grint and Brad Jackson, 251-72. London: Sage, 2011.

Eisenstein, Hester. Contemporary Feminist Thought. Sydney: Allen \& Unwin, 1984.

Eisenstein, Hester. 'The Australian Femocratic Experiment: A Feminist Case for Bureaucracy.' In Feminist Organizations: Harvest of the New Women's Movement, edited by Myra Marx Feree and Patricia Yancey Martin, 69-83. Philadelphia: Temple University Press, 1995.

Eisenstein, Hester. Inside Agitators: Australian Femocrats and the State. Sydney: Allen \& Unwin, 1996.

Eveline, Joan. 'The Politics of Advantage.' Australian Feminist Studies 9(19) (1994): 129-54.

Eveline, Joan. 'The Worry of Going Limp: Are You Keeping Up in Senior Management.' Australian Feminist Studies 11(3) (1996): 65-79.

Fairhurst, Gail. Discursive Leadership: In Conversation with Leadership Psychology. Thousand Oaks, Calif.: Sage, 2007. 
Diversity in Leadership: Australian women, past and present

Ferguson, Kathy. The Feminist Case against Bureaucracy. Philadephia: Temple University Press, 1984.

Ferree, Myra Marx and Patricia Yancey Martin. 'Doing the Work of the Movement: Feminist Organizations.' In Feminist Organizations: Harvest of the New Women's Movement, edited by Myra Marx Ferree and Patricia Yancey Martin, 3-23. Philadelphia: Temple University Press, 1995.

Ferree, Myra Marx and Patricia Yancey Martin, eds. Feminist Organizations: Harvest of the New Women's Movement. Philadelphia: Temple University Press, 1995.

Fletcher, Joyce. Disappearing Acts: Gender, Power and Relational Practice at Work. Cambridge, Mass.: MIT Press, 1999.

Fletcher, Joyce. 'The Paradox of Post Heroic Leadership: An Essay on Gender, Power and Transformational Change.' The Leadership Quarterly 15 (2004): $647-61$.

Ford, Jackie. 'Discourses of Leadership: Gender, Identity and Contradiction in a UK Public Sector Organization.' Leadership 2(1) (2006): 77-99.

Ford, Jackie. 'Studying Leadership Critically: A Psychosocial Lens on Leadership Identities.' Leadership 6(1) (2010): 47-65.

Graham, Pauline. Mary Parker Follett-Prophet of Management: A Celebration of Writings from the 1920s. Boston, Mass.: Harvard Business School Press, 1995.

Grint, Keith. 'A History of Leadership.' In The Sage Handbook of Leadership, edited by Alan Bryman, David Collinson, Keith Grint, Brad Jackson and Mary Uhl-Bien, 3-14. London: Sage, 2011.

Hall, Valerie. Dancing on the Ceiling: A Study of Women Managers in Education. London: Paul Chapman, 1999.

Harding, Sandra. 'Introduction: Is There a Feminist Method?' In Feminism and Methodology, edited by Sandra Harding, 1-14. Bloomington: Indiana University Press, 1987.

Harding, Sandra. Sciences from Below: Feminisms, Postcolonialities, and Modernities. Durham, NC: Duke University Press, 2008.

Hearn, Jeff and P. Wendy Parkin. 'Women, Men and Leadership: A Critical Review of Assumptions, Practices and Change in the Industrialized Nations.' In Women in Management Worldwide, edited by Nancy Adler and Dafna Izraeli, 17-40. Armonk, NY: M. E. Sharpe, 1988. 
Heifetz, Ron. Leadership without Easy Answers. Cambridge, Mass.: Belknap Press, 1994.

Heifetz, Ron and Marty Linsky. Leadership on the Line: Staying Alive through the Dangers of Leading. Boston: Harvard Business School Press, 2002.

Hennig, M. and Ann Jardim. The Managerial Woman. London: Marion Boyars, 1978.

Hooks, Bell. Feminist Theory from Margin to Centre. Boston: South End, 1984.

Hooks, Bell. Talking Back: Thinking Feminist, Thinking Black. Boston: South End Press, 1989.

Höpfl, Heather and Monica Kostera, eds. Interpreting the Maternal Organization. London: Routledge, 2003.

Höpfl, Heather and Sumohom. Matilal. 'The Lady Vanishes: Some Thoughts on Women and Leadership.' Journal of Organizational Change Management 20(2) (2007): 198-208.

Iannello, Kathleen. Decisions without Hierarchy: Feminist Interventions in Organization Theory and Practice. New York: Routledge, 2002.

Kanter, Rosabeth Moss. Men and Women of the Corporation. New York: Basic Books, 1977.

Kellerman, Barbara, ed. Leadership: Multidisciplinary Perspectives. Englewood Cliffs, NJ: Prentice Hall, 1984.

Kellerman, Barbara. Bad Leadership: What it is, How it Happens, Why it Matters. Boston: Harvard Business School Press, 2004.

Ladkin, Donna. 'The Enchantment of the Charismatic Leader: Charisma Reconsidered as Aesthetic Encounter.' Leadership 2(2) (2006): 165-79.

Ladkin, Donna. Rethinking Leadership: A New Look at Old Leadership Questions. Cheltenham, UK: Edward Elgar, 2010.

Lather, Patti. Getting Smart: Feminist Research and Pedagogy with/in the Postmodern. New York: Routledge, 1991.

Lohrey, Amanda. 'A Matter of Context: Gillard and the Press Gallery.' The Monthly 84 (November 2012). http://www.themonthly.com.au/issue/2012/ november/1354241249/amanda-lohrey/matter-context. 
Martin, Patricia Yancey. 'Feminist Practice in Organizations: Implications for Management.' In Women in Management, edited by Ellen Fagenson, 274-296. Thousand Oaks, Calif.: Sage, 1994.

Mohanty, Chandra Talpede. Feminism without Borders: Decolonizing Theory, Practicing Solidarity. Durham, NC, and London: Duke University Press, 2003.

Poggio, Barbara. 'Who's Afraid of Mothers?' In Interpreting the Maternal Organization, edited by Heather Höpfl and Monica Kostera, 13-26. London: Routledge, 2003.

Pringle, Judith. 'Feminism and Management: Critique and Contribution.' In New Directions in Management, edited by Alex Kouzmin, Leonie Still and P. Clarke, 127-42. Sydney: McGraw Hill, 1994.

Raelin, Joe. 'From Leadership-as-Practice to Leaderful Practice.' Leadership 7(2) (2011): 195-211.

Rayner, Moira. 'Gillard, Bligh and Leadership in a Crisis.' Eureka Street 21(2) 7 January 2011. http://www.eurekastreet.com.au/article.aspx?aeid=24745\#. U5PsJPna6m4.

Ropo, Arja and Erica Sauer. 'Corporeal Leaders.' In The Sage Handbook of New Approaches in Management and Organization, edited by Daved Barry and Hans Hansen, 469-78. London: Sage, 2008.

Rosener, Judy. 'Ways Women Lead.' Harvard Business Review (NovemberDecember 1990): 119-25.

Sawer, Marian. Sisters in Suits: Women and Public Policy in Australia. Sydney: Allen \& Unwin, 1990.

Shaw, Jan. 'Papering the Cracks with Discourse: The Narrative Identity of the Authentic Leader.' Leadership 6(1) (2010): 89-108.

Sinclair, Amanda. Trials at the Top: Chief Executives Talk about Men, Women and the Executive Culture. Melbourne: The Australian Centre, 1994.

Sinclair, Amanda. Doing Leadership Differently: Gender, Power and Sexuality in a Changing Business Culture. Melbourne: Melbourne University Press, 1998.

Sinclair, Amanda. 'Bodies Possibilities in Leadership.' Leadership 1(4) (2005): 387-406.

Sinclair, Amanda. Leadership for the Disillusioned: Moving beyond Myths and Heroes to Leading that Liberates. Sydney: Allen \& Unwin, 2007. 
Sinclair, Amanda. 'Leading with Body.' In Handbook of Gender, Work and Organization, edited by Emma Jeanes, David Knights and Patricia Yancey Martin, 117-30. New York: John Wiley \& Sons, 2011.

Summers, Anne. Damned Whores and God's Police: The Colonisation of Women in Australia. Melbourne: Penguin, 1974.

Summers, Anne. 'The Political Persecution of Australia's First Female Prime Minister.' Human Rights and Social Justice Lecture, University of Newcastle, 31 August 2012.

Telford, Andrena. 'Maiden, Mother, Mistress, Monster: Controlled and Uncontrolled Female Power and the Curse of the Body in the Early Victorian Novel-Implications of Historical Stereotyping for Women Managers.' In Interpreting the Maternal Organization, edited by Heather Höpfl and Monica Kostera, 104-20. London: Routledge, 2003.

Uhl-Bien, Mary. 'Relational Leadership Theory: Exploring the Social Processes of Leadership and Organizing.' The Leadership Quarterly 17 (2006): 654-76.

Weedon, Chris. Feminist Practice and Poststructural Theory. Oxford: Blackwell, 1987.

White, Nerida. 'Indigenous Australian Women's Leadership: Stayin' Strong against the Postcolonial Tide.' International Journal of Leadership in Education 13(1) (2010): 7-25.

Williams, Dean. Real Leadership: Helping People and Organizations Face their Toughest Challenges. San Francisco: Berrett-Koehler, 2005.

Young, Michelle and Linda Skrla, eds. Reconsidering Feminist Research in Educational Leadership. Albany, NY: State University of New York Press, 2003. 
This text taken from Diversity in Leadership: Australian women, past and present, edited by Joy Damousi, Kim Rubenstein and Mary Tomsic, published 2014 by ANU Press, The Australian National University, Canberra, Australia. 